\title{
5 Developing digital innovation in family firms
}

\author{
Evidence from Italian industrial \\ districts
}

\author{
Stefano Amato, Alessia Patuelli \\ and Nicola Lattanzi
}

\section{Introduction}

Since the 1970s, the extraordinary growth of spatial agglomerations of manufacturing small and medium-sized enterprises (SMEs) in Italy has attracted the interest of the scientific community in an effort to understand the competitiveness of local networks of flexible and specialized firms, as opposed to the vertically integrated Fordist model. With his pioneering studies, Giacomo Becattini restored the concept of the Marshallian Industrial District (MID), defined as "a social and territorial entity characterized by the active presence of a community of people and a group of firms in a natural and historically delimited area or zone" (Becattini, 1992, 62). In MIDs, competitive advantages are embedded in localization externalities related to a pool of qualified workers, specialized suppliers, localized knowledge, and information (i.e., knowledge spillovers) available in the economic actor networks (Boix \& Trullén, 2010). Both market and community logics govern economic activities in MIDs (Chiarvesio, Di Maria, \& Micelli, 2010), where competitive dynamics stimulating innovativeness are balanced with trust-based cooperation (Boschma \& Lambooy, 2002; Dal Maso \& Lattanzi, 2014). District firms are embedded in a homogenous setting, stemming from belonging to the same community and sharing values, practices, and behaviors. This setting enables the creation of a "Marshallian atmosphere" (Belussi \& Caldari, 2008), bringing various advantages for firms, including a higher level of productiveness/ efficiency (Cainelli \& De Liso, 2005; Signorini, 1994), export performance (Belzo-Martìnez, 2006), and innovation capabilities (Muscio, 2006).

While MIDs represent an ideal environment for the faster diffusion of innovations among firms (Cainelli, 2008), there is an intra-district heterogeneity related to the different abilities of local firms within the district (HervásOliver, Albors-Garrigos, Estelles-Miguel, \& Boronat-Moll, 2018). Indeed, local firms show different patterns in accessing the available knowledge and information flowing in the milieu, which affects the intensity of innovation adoption (Giuliani, 2007). In this perspective, some studies affirm the family status of the firm as a source of intra-district heterogeneity (Pucci, Brumana, Minola, \& Zanni, 2017). This is related to the ability of family firms to exploit 
the territorialized network of knowledge and relationships developed in the district (Cucculelli \& Storai, 2015). However, intra-district heterogeneity related to family firms' innovation appears to be understudied in MIDs.

To address the aforementioned research gap, our chapter, drawing upon a sample of 152 manufacturing firms located in five Italian MIDs, investigates the development of digital innovation among family and non-family firms. In particular, our focus is whether they differ in their approach to digital innovation, focusing on the adoption of technologies related to the fourth industrial revolution, also known as Industry 4.0 (Schwab, 2017). Our results suggest that family firms are more oriented towards Industry 4.0-driven digital innovation than their non-family counterparts. Therefore, our preliminary conclusion, which requires further research in the future, is that while territorialized networks of interconnected firms, such as MIDs, represent a source of dynamic advantages for co-located firms, the family status of the firms seems to matter in explaining the existence of "differential" advantages in the digitalization among them.

The contribution of this book chapter is three-fold. First, to the literature on industrial districts, our study provides new evidence on district firms' innovation performance. However, while a dichotomic approach aimed at ascertaining the performance of firms located in MIDs versus non district firms has traditionally prevailed, our book chapter, focusing on intra-district firm heterogeneity, sheds new light on the existence of specific characteristics that explain why some particular types of firms benefit more from localization externalities than others. Second, it contributes to family firm studies, in line with the latest research efforts intended to include the physical and social-spatial contexts (e.g., Basco, 2015; Baù et al., 2018), our study offers new insights on family firms and MIDs recognizing that family firm specificities matter in industrial districts contexts for adopting digital innovation. Finally, we contribute to digital innovation literature, with a specific interest in Industry 4.0, which is emerging as a promising research topic (Arnold, Kiel, \& Voigt, 2016; Schmidt et al., 2015). This chapter also makes practical contributions by uncovering the importance of firms' family nature when public policies (e.g., the Italian Industry 4.0 plan) aimed at improving the competitiveness of enterprises, local production systems, and regions are tailored.

This chapter is structured as follows. First, we review the literature on industrial districts, family firms, and innovation. Subsequently, we introduce our methodology, illustrating the study design. Finally, we present and discuss our results, concluding with final remarks, contributions, and future research lines.

\section{Theoretical background}

\section{Digital innovation in MIDs}

Innovation, generally regarded as the introduction of a technical or organizational novelty within a firm, a new idea, or behavior (Schumpeter, 1934), 
is a "genetic ability" of MIDs resulting from the combined effects of local rivalry, interaction, and cooperation, which together favor the dissemination of non-codified knowledge and information among district firms (Cainelli, 2008). The socialization processes occurring in the local milieu, backed by the intra-regional mobility of human resources, dense informal local networks, and a common cultural and institutional setting, ease the spontaneous exchange of innovation-relevant knowledge and information (Boschma \& Lambooy, 2002). In this perspective, Boix and Galletto (2009) coined the term "I-district effect", which indicates the existence of a higher innovative intensity in MIDs compared to non-district areas. Current evidence shows a positive association between firms' localization in MIDs and their innovation performance in terms of product innovation (Muscio, 2006) and number of patents (Boix \& Trullén, 2010; Santarelli, 2004), with an above-average rate of innovation both in times of economic stability (Boix \& Galletto, 2009) and during adverse conditions (Boix, Galletto, \& Sforzi, 2019).

MIDs are currently experiencing deep structural transformations, driven by the consequences of the international financial crisis (De Marchi, Lee, \& Gereffi, 2014), the gradual integration of district firms in the global value chain (Chiarvesio, Di Maria, \& Micelli, 2010), the emergence of leading firms with asymmetric market and financial power (Randelli \& Boschma, 2012), and the rise of new digital industrial technologies related to the fourth industrial revolution, generally known as Industry 4.0 (Bellandi, De Propris, \& Santini, 2019a).

Today, Industry 4.0 is emerging as a new type of digital innovation (Kang et al., 2016) that is establishing the premises for a manufacturing "renaissance" and socioeconomic development (Bellandi, Lombardi, \& Santini, 2019 b). It is aimed at transforming firms' value creation and business models with digitalization, automation, and robotics (Götz \& Jankowska, 2017), ultimately changing the traditional source of competitiveness of both firms and regions (Schwab, 2017). Technologies related to Industry 4.0 include simulation, augmented reality, robots, Internet of Things (IoT), cloud services, cybersecurity, additive manufacturing, horizontal and vertical system integration, Big Data, and analytics (Wang \& Wang, 2016). MIDs, traditionally characterized by a strong manufacturing specialization (Becchetti, De Panizza, \& Oropallo, 2007), perceive digital technologies related to Industry 4.0 as both threats and opportunities (Bellandi et al., 2019b). However, how and to what extent district firms adjust their structures to the new technological paradigm will depend on the combined efforts of local institutions and public policy initiatives, ${ }^{1}$ as well as firms' specific characteristics.

In terms of firms' specific characteristics, as a source of intra-district heterogeneity (Cucculelli \& Storai, 2015; Pucci et al., 2017), the family status of the firm might be one reason that explains different levels of digital innovation adoption in MIDs. The lack of research on family firms in MIDs is paradoxical since MIDs represent a long-lasting localization (Belussi \& Caldari, 2008) and a natural socio-spatial basin of entrepreneurial families. In these 
contexts, the phenomenon of family in business renews itself across generations, becoming a pervasive institution for creating social structures that drive MIDs' evolution (Randelli \& Boschma, 2012). In MIDs, family firms generally show a superior position in inter-organizational and inter-personal networks (Cucculelli \& Storai, 2015), which may result in a firm-specific capability in intercepting and exploiting a knowledge-rich local environment (Lattanzi, 2017). These specificities, in turn, can affect the extent to which family firms belonging to industrial districts engage in new digital and technological innovations as compared to their non-family counterparts.

\section{Family firms and digital innovation in MIDs}

Family firms are a widespread phenomenon across Europe. While they are the most pervasive form of organization among all OECD nations and European nations in general, accounting respectively for $85 \%$ and $70-80 \%$ of all companies (Alberti \& Pizzurno, 2013; Mandl, 2008); these percentages are even higher in Italy. Family firms are the backbone of both Italian MIDs (Intesa San Paolo, 2018) and the national economy - more than $85 \%$ of enterprises are family firms, and they generate $70 \%$ of total employment (AIDAF, 2018). Family firms show specific behaviors that differ from non-family firms in many ways (Alberti \& Pizzurno, 2013). The core reason of their peculiar behaviors resides in the so-called "familiness", a unique characteristic that can lead to certain synergies, advantages, and disadvantages (Pearson, Carr, \& Shaw, 2008). Familiness can influence a number of aspects, including goals (Tagiuri \& Davis, 1992), corporate governance (Golinelli, 2000; Randoy, Jenssen, \& Goel, 2003), financial structure (López-Gracia \& Sánchez-Andújar, 2007), and entrepreneurship orientation (Zahra \& Sharma, 2004). It can also influence innovation in different ways (Calabrò et al., 2019). On one side, family firms might be more conservative, less entrepreneurial, rigid, risk-averse, more willing to keep control, resistant to change, and more reluctant to pioneering new products, processes, and markets (Kraus, Pohjola, \& Koponen, 2012). They also usually have more limited access to capital markets and may be less eager to grow (Craig, Pohjola, Kraus, \& Jensen, 2014). On the other hand, family firms typically have a long-term orientation and the capacity to involve multiple generations, which may affect innovation dynamics (Nieto, Santamaria, \& Fernandez, 2015). Overall, family firms' equilibrium of internal forces can lead to fostering or limiting innovation (Ingram, Lewis, Barton, \& Gartner, 2016).

Having said that, it is not the family condition of the firm per se that determines its innovativeness orientation but the unique connections that firms are able to establish with their territory or place (Smith, 2016). In particular, family firms are regarded as having tight links with their territory, with a strong interdependence between their economic activity and their place. There is an interactive relationship with the milieu and a feeling of identity and attachment of family members to the place (Kim, Haider, Wu, \& Dou, 2019). 
Family firms are generally committed to renewing and reshaping their social interactions, both within and outside the family domain, as a way to access valuable resources (Salvato \& Melin, 2008), hence differing in the way they interact with their surroundings (Basco, 2015). Even though the literature on family firms and innovation is growing, only recently have scholars begun to explore how these peculiar organizations behave when located in MIDs. For instance, by drawing on a large sample of Italian manufacturing district firms, Cucculelli and Storai (2015) show how the advantage of being located in MIDs (i.e., district effect) is dependent upon the size of family firms with only the medium-sized ones being able to leverage the localization benefits of MIDs, reflected in a level of higher profitability when compared with non-district firms. With regard to the innovation performance in geographical clusters of firms, Pucci et al. (2017) show how family firms are better able to leverage the localized network of relationships, positively affecting their innovation capability.

The specific traits of family firms appear to be well-suited for MIDs (Cucculelli \& Storai, 2015). Social capital arises as a critical asset in explaining how local knowledge and innovation-relevant information is gathered, regenerated, and shared among district firms (Malecki, 2012). Conceived as a relational asset based on trust, norms, and reciprocity (Coleman, 1988), social capital alludes to the development and exploitation of social ties among actors in a local network (Lambooy, 2010). In MIDs, it is both a "lubricant" for firms' organizational decisions and a "glue" for the local production system as a whole (Bertolini \& Giovannetti, 2006).

Family firms are generally endowed with firm-specific social capital (Zahra, 2010) based on interdependence and trustworthiness among family members (i.e., "internal social capital"), which tends to be replicated outside the organization (Arregle, Hitt, Sirmon, \& Very, 2007) (i.e., "external social capital"). Family members show a certain degree of closure and centrality in local entrepreneurial networks, resulting in social and professional ties strengthened by trust (Anderson, Jack, \& Dodd, 2005). This is particularly true in MIDs, where there are blurred boundaries between informal and formal networks (Chetty \& Agndal, 2008). Therefore, family firms located in MIDs are more likely to show a differential advantage than non-family firms (Hess, 2004).

Indeed, while geographical proximity favors contacts and facilitates the exchange of tacit knowledge (Boschma, 2005), the inherent willingness of family firms to establish socially proximate relationships with local actors reduces the risk of opportunistic behavior, enhancing interactive learning and innovation capabilities (Baù et al., 2018). Additionally, while shared values, norms, and agreements mediate interactions within MIDs (Dei Ottati, 2002), family firms play a crucial role in the sedimentation of local institutional mechanisms (Raco, 1999). Hence, a higher level of institutional proximity of family firms facilitates the access to and the transfer of tacit knowledge in district networks (Soleimanof, Rutherford, \& Webb, 2018). 
Finally, the high level of specialization of MIDs results in a common knowledge base that enables mutual understanding among local actors. The local embeddedness of family firms results in a shared language and domain of a district-specific knowledge, continuously transmitted to generations, which facilitates effective communication and interactive learning needed to successfully engage in innovative activities (Anselmi \& Lattanzi, 2016).

Based on the above-mentioned arguments, we infer the existence of intra-district heterogeneity based on firms' family status ${ }^{2}$ with an impact on firms' ability to innovate. Firm-specific social capital, as reflected in the centrality and closure in the local networks, and strong territorial embeddedness enable family firms to alter the social and economic relationships underlying the dissemination of knowledge and information in MIDs, which is relevant for digital innovation adoption and exploitation. Thus, we propose the following hypothesis:

Hypothesis: The pace of digital innovation in MIDs is higher for family firms than for their non-family counterparts

\section{Empirical design}

To test our hypothesis, we relied on a dataset from a survey carried out by the research unit of Intesa Sanpaolo (Direzione Studi e Ricerche Intesa Sanpaolo). ${ }^{3}$ The survey was aimed at capturing information on the strategies, innovation patterns, international trade, ownership, and management structures of a sample of manufacturing firms located in industrial districts across three Italian regions: Piedmont, Tuscany, and Veneto. ${ }^{4}$ In particular, the leather and jewelry districts of Arzignano, Santa Croce sull'Arno, Vicenza, Arezzo, and Valenza were chosen. ${ }^{5}$ Firms were identified using the ATECO $\operatorname{code}^{6}$ and the province of operations. The initial sample included 584 firms. Those in liquidation or non-active ones were not included. The survey was sent to each firm between October 2018 and February 2019. Reminders were sent in seven instances, approximately 14 days apart from each other. Eventually, 158 firms completed the questionnaire with a response rate of $27 \%$. It is worth noting that selection bias might have occurred as data collection was part of a wider project. However, pure random samples are difficult to find in family firm research, as a national family firm database does not exist (Beck, Janssens, Debruyne, \& Lommelen, 2011).

Additionally, survey-based information was complemented with accounting data retrieved from Aida-Bureau Van Dijk, a database containing the historical financial and commercial data from approximately 540,000 companies operating in Italy. After removing companies not included in Aida, we obtained a final dataset consisting of 152 companies, the width of which is comparable to others used in family business research (Beck et al., 2011; Cucculelli, Le Breton-Miller, \& Miller, 2016). 
Table 5.1 Description of variables

Variables
Dependent variables
Industry 4.0

Independent variable

Family firm

\section{Control variables \\ Age \\ Size \\ Human capital \\ Export intensity \\ $R \& D$ intensity \\ Product innovations}

Process innovations

Organizational innovations

Foreign share

\section{Other controls}

Industry

Province
Description

Likert scale (1-5) measuring the intensity with which firm $i$ is currently investing in Industry 4.0-related technologies

Dummy variable coded "1" if the majority of the equity is held by a family and at least two family members are formally involved in the governance of the firm, " 0 " otherwise

Number of years a firm exists since its foundation Logarithmic transformation of total assets

Ratio of graduated to total of employees

Ratio of foreign sales to total sales

Ratio of R\&D expenditures to total sales

Dummy variable coded " 1 " if in the last three-year period firm $i$ has introduced product innovations, " 0 " otherwise

Dummy variable coded "1" if in the last three-year period firm $i$ has introduced process innovations, " 0 " otherwise

Dummy variable coded "1" if in the last threeyear period firm $i$ has introduced organizational innovations, "0" otherwise

Dummy variable coded " 1 " if a foreign investor is present in the equity of the firm $i$, " 0 " otherwise

Industry in which firm $i$ operates: leather and jewelry Province in which firm $i$ is headquartered: Piedmont, Tuscany and Veneto

Table 5.1 shows the variables employed in our study. The dependent variable (Industry 4.0) measures the degree to which firms are committed to digital innovation, with a specific reference to investments in new digital technologies related to the fourth industrial revolution. As constructs to measure the development of digital innovations related to Industry 4.0 are still scarce, we adapted one item from the Kellermanns, Eddleston, Sarathy, and Murphy (2012) innovation scale, ${ }^{7}$ based on a five-point Likert scale, where 1 is a strongly negative and 5 a strongly positive commitment to firm's digitalization.

Our variable of interest is the family nature of the firm (Family firm). As the definition of family firm is a debated issue, we followed the so-called "demographic approach" to identifying them, which posits the mere involvement of the family members in the firm - ownership, control, or management - as a sufficient condition for capturing the influence of the family on the firm 
(Basco, 2013). Accordingly, we defined it as a family firm if two not mutually exclusive conditions occur: (i) the majority of decision-making rights are in the possession, both directly and indirectly, of either the entrepreneur who established the firm or persons linked to the founder by family relationships; and, (ii) two or more family members sit on the board of directors of the firm. ${ }^{8}$ Finally, we controlled for other firm-level characteristics that may affect firms' commitment to digitalization.

With the purpose of investigating the association between the family nature of the firm and digital innovation in the context of industrial districts, we estimate the following model:

Industry $4.0_{i}=\alpha_{0}+$ BlFamily firm ${ }_{i}+\beta_{2}$ Size $_{t}+\beta_{3}$ Age $_{i}+\beta_{4}$ Human Capital $_{i}+\beta_{5}$ Export intensity $_{i}+\beta_{6}$ Absorptive capacity $_{i}+\beta_{7}$ Product innovation $_{i}+\beta_{8}$ Process innovation $_{i}+\beta_{9}$ Organizational innovation $_{i}+$ $\beta_{10}$ Foreing share $_{i}+\gamma I_{i}+\delta P_{i}+\varepsilon_{i}$

where $\alpha_{0}$ is the constant, $\beta_{1}$ is the coefficient of our variable of interest, $I_{i}$ and $P_{i}$ are respectively the industry-specific and province-specific dummy effects, $\gamma$ and $\delta$ are the vectors corresponding to the coefficients, and $\varepsilon_{i}$ is the error term. We address heteroscedasticity concerns in our estimations by computing heteroscedasticity-robust standard errors.

\section{Findings}

The descriptive statistics and pairwise Pearson correlation are reported in Tables 5.2 and 5.3, respectively. In particular, Panel 2A shows the descriptive statistics for the whole sample. Family firms account for $42 \%$ of the total sample, corresponding to 64 of the 152 firms. On average, sampled firms are 30 years old, export more than $40 \%$ of their sales, and are overwhelmingly

Table 5.2 Descriptive statistics

Panel 5.2A Descriptive statistics for the whole sample

\begin{tabular}{lccccc}
\hline Variable & Obs. & Mean & St. dev. & Min & Max \\
\hline Industry 4.0 & 152 & 2.460 & 1.390 & 1 & 5 \\
Family firm & 152 & 0.421 & 0.495 & 0 & 1 \\
Size & 152 & 7.772 & 1.436 & 4.651 & 10.870 \\
Age & 152 & 30.01 & 15.473 & 3 & 64 \\
Human capital & 152 & 4.085 & 9.305 & 0 & 75 \\
Export intensity & 152 & 42.407 & 34.612 & 0 & 100 \\
R\&D intensity & 152 & 6.690 & 12.852 & 0 & 90 \\
Product innovation & 152 & 0.493 & 0.501 & 0 & 1 \\
Process innovation & 152 & 0.348 & 0.478 & 0 & 1 \\
Organizational innovation & 152 & 0.276 & 0.448 & 0 & 1 \\
Foreign share & 152 & 0.026 & 0.160 & 0 & 1 \\
\hline
\end{tabular}

${ }^{\mathrm{L}}$ Expressed in natural logarithm. 
Panel 5.2B Difference of means and Wilcoxon rank-sum test

\begin{tabular}{|c|c|c|c|c|c|}
\hline \multirow[t]{2}{*}{ Variable } & \multirow{2}{*}{$\begin{array}{l}\text { Non- } \\
\text { family } \\
\text { firms }\end{array}$} & \multirow[t]{2}{*}{$\begin{array}{l}\text { Family } \\
\text { firms }\end{array}$} & \multicolumn{2}{|c|}{$\begin{array}{l}\text { Test for difference } \\
\text { of means }\end{array}$} & \multirow{2}{*}{$\begin{array}{l}\text { Wilcoxon } \\
\text { rank-sum test }\end{array}$} \\
\hline & & & $\begin{array}{l}\text { Difference } \\
\text { of means }\end{array}$ & $\mathrm{t}$-statistics & \\
\hline Industry 4.0 & 2.227 & 2.781 & -0.554 & $-2.466^{* *}$ & $-2.417^{* *}$ \\
\hline Size $e^{\mathrm{L}}$ & 8.153 & 7.495 & -0.658 & $-2.855^{* * *}$ & $-4.088^{* * *}$ \\
\hline Age & 25.784 & 35.828 & -10.044 & $-4.159^{* * *}$ & $-2.642^{* *}$ \\
\hline Human capital & 2.830 & 5.812 & -2.982 & $-1.969^{*}$ & $-1.981^{*}$ \\
\hline Export intensity & 35.386 & 52.062 & -16.676 & $-3.010^{* *}$ & $-3.123^{* *}$ \\
\hline$R \& D$ intensity & 5.886 & 7.796 & -1.910 & $-0.904^{+}$ & $-1.670^{+}$ \\
\hline Product innovation & 0.431 & 0.578 & -0.146 & $-1.788^{+}$ & -1.775 \\
\hline Process innovation & 0.318 & 0.390 & -0.072 & -0.921 & -0.922 \\
\hline $\begin{array}{l}\text { Organizational } \\
\text { innovation }\end{array}$ & 0.284 & 0.265 & 0.018 & 0.249 & 0.251 \\
\hline Foreign share & 0.034 & 0.015 & 0.018 & 0.698 & 0.700 \\
\hline Observations & 88 & 64 & & & \\
\hline
\end{tabular}

${ }^{\mathrm{L}}$ Expressed in natural logarithm. ${ }^{\mathrm{W}}$ Winsor at $1 \%$ and $99 \%$ tail. Level of statistical significance $+p<0.10,{ }^{*} p<0.05,{ }^{* *} p<0.01,{ }^{* * *} p<0.001$. ${ }^{\mathrm{a}}$ The Wilcoxon rank-sum test analyses whether the two samples are from different distributions (Sample 1: Non-family firms; Sample 2: Family-firms).

held by domestic owners. For a more straightforward depiction of the difference between family and non-family firms, Panel $2 \mathrm{~B}$ reports the mean of the variables grouped by the nature of the firms along with the results of a test for differences in the means and the results of Wilcoxon rank-sum tests. The results show that family firms are more committed to digital innovation than their non-family counterparts (2.781 versus $2.227, p<0.05)$. Additionally, family firms are smaller, older, and more internationalized, and these differences are statistically significant. With regard to the innovation inputs, the descriptive statistics show that family firms devote more efforts in R\&D activities, considering the respective sales levels, than their non-family counterparts $(7.796$ versus $5.886, p<0.10)$. An analysis of the variance inflation factors (VIFs), shown in Table 5.3, rules out multicollinearity concerns in our data; all the VIF coefficients are below the generally accepted threshold of 10 (Bird \& Wennberg, 2014).

The results of the econometric analysis are reported in Table 5.4. We estimated our coefficients by using the ordinary least squares (OLS) method. Overall, $21 \%$ of the variance of the response variable is explained by the covariates included in the model. Among the control variables, the coefficient of Size is positive and statistically significant $(\beta=0.222, p<0.001)$, indicating that larger firms are in a better position to sustain investments in Industry 4.0. Additionally, the firm's digitalization appears to be contingent on the innovative results achieved by the district firms. In fact, Table 5.4 shows a positive association between Product innovation and Process innovation and the adoption of Industry 4.0 technologies. Surprisingly, the ratio of graduated human 
112 Stefano Amato et al.

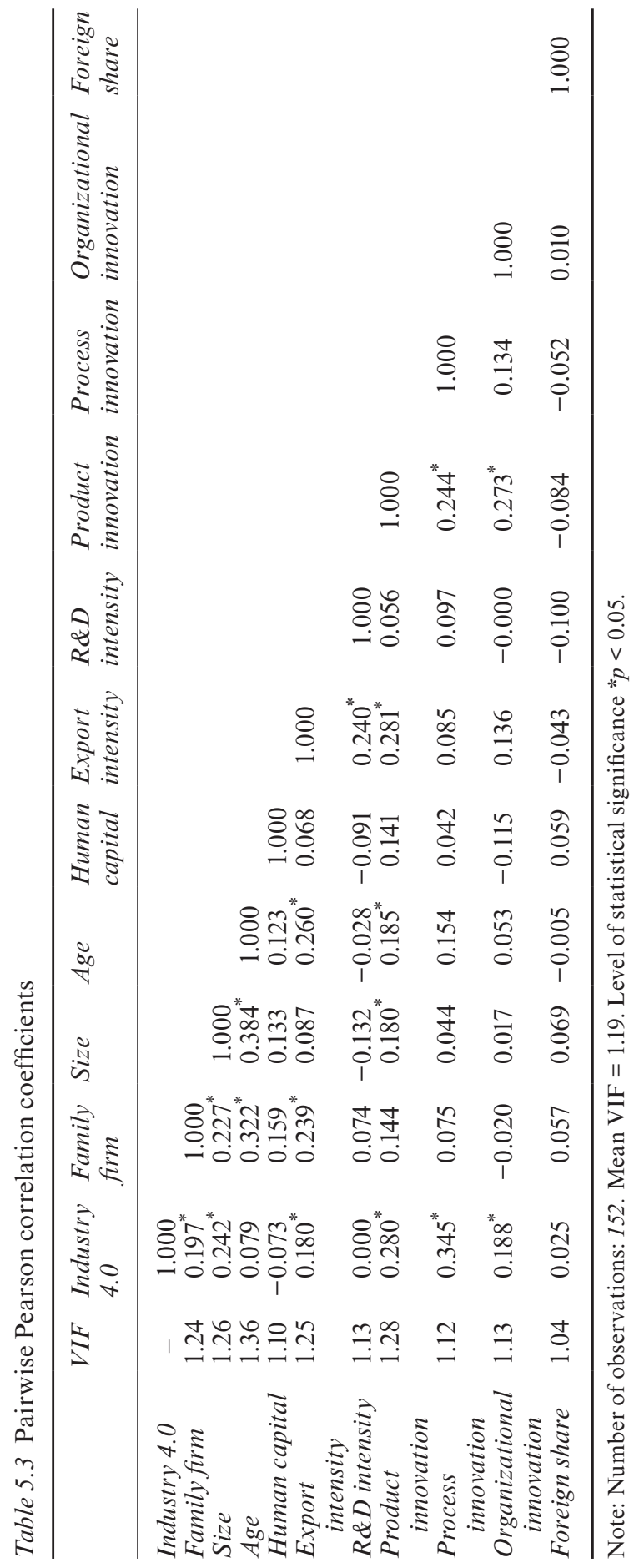


Table 5.4 Regression results

\begin{tabular}{|c|c|}
\hline \multicolumn{2}{|c|}{ Dependent variable: Industry 4.0} \\
\hline Family firm & $\begin{array}{c}0.456^{*} \\
(0.226)\end{array}$ \\
\hline Size & $\begin{array}{c}0.222^{* *} \\
(0.077)\end{array}$ \\
\hline Age & $\begin{array}{c}-0.012 \\
(0.008)\end{array}$ \\
\hline Human capital & $\begin{array}{c}-0.023^{* *} \\
(0.008)\end{array}$ \\
\hline Export intensity & $\begin{array}{c}0.004 \\
(0.003)\end{array}$ \\
\hline$R \& D$ intensity & $\begin{array}{r}-0.006 \\
(0.007)\end{array}$ \\
\hline Product innovation & $\begin{array}{c}0.405^{+} \\
(0.219)\end{array}$ \\
\hline Process innovation & $\begin{array}{l}0.911^{* * *} \\
(0.223)\end{array}$ \\
\hline Organizational innovation & $\begin{array}{c}0.257 \\
(0.247)\end{array}$ \\
\hline Foreign share & $\begin{array}{c}-0.334 \\
(0.634)\end{array}$ \\
\hline Industry & YES \\
\hline Province & YES \\
\hline Constant & $\begin{array}{c}0.147 \\
(0.627)\end{array}$ \\
\hline Observations & 152 \\
\hline Adjusted R-Squared & 0.210 \\
\hline
\end{tabular}

resources has an adverse effect on a firm's digitalization. In fact, the coefficient of Human capital is negative and statistically significant $(\beta=-0.023$, $p<0.001$ ). The remaining controlling variables reveal that neither in-house $\mathrm{R} \& \mathrm{D}$ activities (i.e., $R \& D$ intensity) nor the degree of internationalization (i.e., Export intensity) affect the adoption of digital innovations.

With regard to the explanatory variable, our findings show that within industrial districts, all things being equal, family firms pursue digital innovation more intensively than non-family firms, as reflected in the adoption of technologies related to Industry 4.0. Indeed, the coefficient of our variable of interest (Family firm) is positive and statistically significant ( $\beta=0.456$, $p<0.05$ ), hence providing support for our hypothesis.

\section{Final remarks}

The contemporary industrial revolution, which encompasses the digitalization of manufacturing through the adoption of Industry 4.0 technologies, 
is initiating an unparalleled transition to new ways of production, business models, modes of value creation, and distribution systems. Local production systems such as MIDs, characterized by a strong manufacturing specialization, are highly exposed to the new technological paradigm, which is a source of threats and opportunities for industrial district firms. While localization in MIDs favors increasing returns and superior technological performance because of the potential access to localization externalities, some firms are in a better position than others to leverage the industrial district's advantages. In particular, the concept of "intra-district heterogeneity" has emerged as a new research area aimed at understanding which firm-specific characteristics explain some firms' unique abilities to exploit district knowledge and information. Among the sources of heterogeneity, the family status of the firm has been historically overlooked by the industrial district and cluster literature.

To address the aforementioned research gap, we draw on survey microdata of Italian firms located in five MIDs to explore whether family firms develop more digital innovations related to the fourth industrial revolution (Industry 4.0) than their non-family counterparts. Our findings reveal that family firms are more prone to adopt digital innovations related to Industry 4.0. Hence, compared to their non-family counterparts, family firms are more actively preparing to compete in the new technological wave, playing a crucial role in the transformation of MIDs. This research shows that the distinctive characteristics of family firms adapt well to the peculiarities of industrial districts, where the social dimension of economic activities (a set of informal, trustbased, and reciprocal relationships regulated by a shared system of cultural values) distinguishes MIDs from other types of local production systems (e.g., business cluster). Due to the rich social capital and high degree of embeddedness in the local network, family firms are in a unique position to intercept and exploit the relevant knowledge and information that flows freely in the industrial district. Hence, while the localization in MIDs is a source of both static and dynamic advantage for co-located firms, family firms appear to benefit more from externalities and the resulting localization economies, as reflected in a higher pace of digital innovation than their non-family counterparts.

This study makes several contributions. First, for the industrial district and cluster literature, we shed new light on the digital innovation taking place inside MIDs. However, different from the prevailing approach aimed at measuring the so-called "I-MID effect" (i.e., the existence of a dynamic efficiency in the form of a positive innovative differential compared to non-district firms), we provide new evidence on so-called "intra-district heterogeneity," highlighting whether and to what extent some firm-specific characteristics account for differential advantages. Testing the family status of the firm as a source of intra-district heterogeneity, we extend the results of Hervás-Oliver, Sempere Ripoll, Estelles-Miguel, and Rojas (2019), who found how firms with higher absorptive capacity are able to exploit a knowledge-abundant milieu, such as MIDs. 
Second, we contribute to the family business innovation literature. We explore family firms' development of digital innovation with the adoption of Industry 4.0-related technologies. Whereas Industry 4.0 is receiving increasing interest in Europe (Schmidt et al., 2015), research is just starting to explore the topic (Arnold et al., 2016), showing that SMEs are not yet fully exploiting the advantages of Industry 4.0 (Moeuf et al., 2018). However, our chapter shows some evidence that family firms are more inclined towards such transformation. Additionally, we contribute to the growing efforts geared towards the inclusion of the physical-relational space for the comprehension of family firms' behavior and performance (e.g., Basco, 2015; Stough et al., 2015). In this perspective, while the interplay between family and business domains has emerged as the traditional lens to explain the distinctiveness of family firms towards innovation, the incorporation of the spatial dimension - that is, the firm's localization in MIDs - unveils further valuable insights for the comprehension of family business innovation. Even though MIDs are a source of dynamic advantages for co-located firms, the family firm's specific social capital and its superior position (i.e., embeddedness) in the territorialized network of relationships confer a differential ability to benefit from agglomeration economies.

Our study has relevant implications for policy makers. Industrial districts, as the backbone of Italian manufacturing systems and a source of regional competitiveness, are experiencing deep changes. Driven by the consequences of the international financial crisis, these include the growing reliance on outsourcing, the integration in the global value chain, the emergence of vertically-integrated firms, and new digital innovations, which, together, are reducing industrial districts' internal cohesion. Therefore, the fourth industrial revolution may represent an opportunity for the upgrading and "revitalization" of district firms and areas as a whole. In this light, national governments across Europe, including Italy, have been promoting measures for all enterprises to support investments in digital transformation. Since our chapter unveils the distinct reaction of family firms located in industrial districts to this new way of digital-driven disruption, the design and evaluation of the effectiveness of these policy initiatives should consider family firms as peculiar actors for the development strategies of local and regional economies. To this end, it is worth noting the peculiar criticalities of family firms that undermine their competitiveness and survivability such as ownership and leadership transition, the need of professionalization, and cultural rigidity - which thus necessitate tailored-made policies (Basco \& Bartkevičiūtè, 2016).

This study has some limitations that pave the way for future research. As our data pertains to only five Italian MIDs specialized in two industries (i.e., leather and jewelry), the possibility of generalizing the findings is rather limited. Hence, future research should explore the digital transformation of family and non-family firms across multiple heterogeneous MIDs and across a wider time span (i.e., longitudinal studies). Additionally, 
comparative studies of MIDs with different levels of technological sophistication may unveil specific patterns of innovation among family and non-family firms. In this regard, the nexus of family-firms and MIDs is a promising research area worth exploring by means of qualitative methods as well, which may complement quantitative ones to investigate the organizational and socio-spatial dynamics taking place in the district areas. Social capital and spatial embeddedness theories could contribute to efforts to interpret such phenomena. Since the district effect is also related to static advantages, as reflected in higher levels of productivity/efficiency compared to firms located in non-district areas, future research should consider firms' family status to explore the existence of differential financial advantages in addition to those related to innovation. Finally, future research could also investigate whether and to what extent family firms, as compared to their non-family counterparts, have contributed to the resilience of MIDs in the face of the global financial crisis of 2007-2008 and to their structural transformations such as the growing integration of district firms in the global value chain.

\section{Acknowledgments}

We would like to thank Giovanni Foresti and Sara Giusti of Intesa Sanpaolo Research Unit (Direzione Studi e Ricerche Intesa Sanpaolo) as part of the joint research program with IMT School for Advanced Studies Lucca.

\section{Notes}

1 As the empirical part of this research is set in Italy, it is worth noting that the "Industria 4.0" national plan, launched in 2017 as part of a European strategy (European Parliament, 2015), provides $€ 18$ billion in funding to support industrial change, promoting investments in innovation, technology, and skills. Even though the plan incorporated all firms, without any dimensional, sectorial, or territorial limit, it mostly targeted SMEs (Italian Ministry of Economic Development, 2017), the majority of which are family firms.

2 While MIDs embody a knowledge-abundant platform favoring inter-firm knowledge and information exchange, we echo Hervàs-Oliver et al. $(2019,1927)$, according to whom "this rich environment [MIDs], however, cannot be exploited equally by collocated firms. On the contrary, collocated firms perform differently."

3 Intesa Sanpaolo is one of the largest banking groups in Italy, and its research unit is mainly concerned with the study of industry and banking dynamics, macroeconomic analysis, equity and credit research and international network research. For more information, please refer to: https://group.intesasanpaolo.com/ it/research.

4 Such regions, respectively situated in the northwest, center, and northeast of Italy, are relevant for the high level of productive specialization and for having experienced higher economic growth than other regions (Storper, 1993).

5 The most outstanding contribution for the identification of MIDs is the methodology elaborated by Sforzi (2002), which suggests the use of Local Labour Markets (LLSs) to identify them. According to the latest census of ISTAT (Italian 
National Institute of Statistics) carried out in 2011, Italy counts 141 industrial districts located mostly in the northeast of the country (45) and specialized in the sectors related to the so-called "Made in Italy" initiative: mechanical industry $(27.0 \%)$, clothing/textiles $(22.7 \%)$, furniture $(17.0 \%)$, and leather and shoes $(12.1 \%)$. For further information, please refer to ISTAT (2011).

6 ATECO (Classification of Economic Activity) is the Italian version of the European nomenclature of NACE Rev. 2 of manufacturing activities.

7 The item measures to what extent firms are currently developing digital innovations by means of Industry 4.0 technologies.

8 It is worth nothing the adopted definition is very similar to that proposed by the European Commission (2009). We raised the threshold of family members involved in corporate governance to at least two members of the owning family instead of the traditional threshold of one member. Our variant has the main advantage of being more stringent than those usually found in the literature, hence ensuring a clearer demarcation between lone-founder and family-owned and governed firms.

\section{References}

AIDAF. (2018). Dieci anni di capitalismo familiare. X osservatorio AUB.

Alberti, F. G., \& Pizzurno, E. (2013). Technology, innovation and performance in family firms. International Journal of Entrepreneurship and Innovation Management, 17(1-3), 142-161.

Anderson, A. R., Jack, S. L., \& Dodd, S. D. (2005). The role of family members in entrepreneurial networks: Beyond the boundaries of the family firm. Family Business Review, 18(2), 135-154.

Anselmi, L., \& Lattanzi, N. (2016). Il Family Business Made in Tuscany. Milano: Franco Angeli.

Arnold, C., Kiel, D., \& Voigt, K.-I. (2016). How the industrial internet of things changes business models in different manufacturing industries. International Journal of Innovation Management, 20(8), 1640015.

Arregle, J.-L., Hitt, M. A., Sirmon, D. G., \& Very, P. (2007). The development of organizational social capital: Attributes of family firms. Journal of Management Studies, 44(1), 73-95.

Basco, R. (2013). The family's effect on family firm performance: A model testing the demographic and essence approaches. Journal of Family Business Strategy, 4(1), 42-66.

Basco, R. (2015). Family business and regional development - A theoretical model of regional familiness. Journal of Family Business Strategy, 6(4), 259-271.

Basco, R., \& Bartkevičiūtè, I. (2016). Is there any room for family business into European Union 2020 strategy? Family business and regional public policy. Local Economy, 31(6), 709-732.

Baù, M., Chirico, F., Pittino, D., Backman, M., \& Klaesson, J. (2018). Roots to grow: Family firms and local embeddedness in rural and urban contexts. Entrepreneurship Theory and Practice, 43(2), 360-385.

Becattini, G. (1992) El distrito industrial marshalliano como concepto socioecono'mico. In F. Pyke, G. Becattini, \& W. Sengenberger (Eds.), Los distritos industriales y las pequenas empresas I. Distritos industriales y cooperacio'n interempresarial en Italia (pp. 61-79). Madrid: Ministerio de Trabajo y Seguridad Social. 
Becchetti, L., De Panizza, A., \& Oropallo, F. (2007). Role of industrial district externalities in export and value-added performance: Evidence from the population of Italian firms. Regional Studies, 41(5), 601-621.

Beck, L., Janssens, W., Debruyne, M., \& Lommelen, T. (2011). A study of the relationships between generation, market orientation, and innovation in family firms. Family Business Review, 24(3), 252-272.

Bellandi, M., De Propris, L., \& Santini, E. (2019a). Industry 4.0 + challenges to local productive systems and place-based integrated industrial policies. In P. Bianchi, C. R. Durán, \& S. Labory (Eds.), Transforming Industrial Policy for the Digital Age: Production, Territories and Structural Change (pp. 201-218). Cheltenham: Edward Elgar Publishing.

Bellandi, M., Lombardi, S., \& Santini, E. (2019b). Traditional manufacturing areas and the emergence of product-service systems: the case of Italy. Journal of Industrial and Business Economics, 47(2), 311-331.

Belussi, F., \& Caldari, K. (2008). At the origin of the industrial district: Alfred Marshall and the Cambridge school. Cambridge Journal of Economics, 33(2), 335-355.

Belzo-Martìnez, J. A. (2006). Do industrial districts influence export performance and export intensity? Evidence for Spanish SMEs' internationalization process, European Planning Studies, 14(6), 791-810.

Bertolini, P., \& Giovannetti, E. (2006). Industrial districts and internationalization: The case of the agri-food industry in Modena, Italy. Entrepreneurship and Regional Development, 18(4), 279-304.

Bird, M., \& Wennberg, K. (2014). Regional influences on the prevalence of family versus non-family start-ups. Journal of Business Venturing, 29(3), 421-436.

Boix, R., \& Galletto, V. (2009). Innovation and industrial districts: A first approach to the measurement and determinants of the I-district effect. Regional Studies, 43(9), 1117-1133.

Boix, R., Galletto, V., \& Sforzi, F. (2019). Place-based innovation in industrial districts: the long-term evolution of the iMID effect in Spain (1991-2014). European Planning Studies, 27(10), 1940-1958.

Boix, R., \& Trullén, J. (2010). Industrial districts, innovation and I-district effect: territory or industrial specialization? European Planning Studies, 18(10), $1707-1729$.

Boschma, R. A. (2005). Proximity and innovation: A critical assessment. Regional Studies, 39(1), 61-74.

Boschma, R. A., \& Lambooy, J. G. (2002). Knowledge, market structure, and economic coordination: Dynamics of industrial districts. Growth and Change, 33(3), 291-311.

Cainelli, G. (2008). Spatial agglomeration, technological innovations, and firm productivity: Evidence from Italian industrial districts. Growth and Change, 39(3), 414-435.

Cainelli, G., \& De Liso, N. (2005). Innovation in industrial districts: Evidence from Italy. Industry and Innovation, 12(3), 383-398.

Calabrò, A., Vecchiarini, M., Gast, J., Campopiano, G., De Massis, A., \& Kraus, S. (2019). Innovation in family firms: A systematic literature review and guidance for future research. International Journal of Management Reviews, 21(3), 317-355.

Chetty, S., \& Agndal, H. (2008). Role of inter-organizational networks and interpersonal networks in an industrial district. Regional Studies, 42(2), 175-187. 
Chiarvesio, M., Di Maria, E., \& Micelli, S. (2010). Global value chains and open networks: The case of Italian industrial districts. European Planning Studies. 18(3), 333-350.

Coleman, J. S. (1988). Social capital in the creation of human capital. American Journal of Sociology, 94, 95-120.

Craig, J. B., Pohjola, M., Kraus, S., \& Jensen, S. H. (2014). Exploring relationships among proactiveness, risk-taking and innovation output in family and non-family firms. Creativity and Innovation Management, 23(2), 199-210.

Cucculelli, M., \& Storai, D. (2015). Family firms and industrial districts: Evidence from the Italian manufacturing industry. Journal of Family Business Strategy, 6(4), 234-246.

Cucculelli, M., Le Breton-Miller, I., \& Miller, D. (2016). Product innovation, firm renewal and family governance. Journal of Family Business Strategy, 7(2), 90-104.

Dal Maso, L., \& Lattanzi, N. (2014). Local firms' strategies and cluster coopetition in Tuscany: The case of "Toscana Promozione" Agency. Problems and Perspectives in Management, 12(1), 132-142.

De Marchi, V., Lee, J., \& Gereffi, G. (2014). (eds.), Globalization, recession and the internationalization of industrial districts: Experiences from the Italian gold jewellery industry. European Planning Studies, 22(4), 866-884.

Dei Ottati, G. D. (2002). Social concertation and local development: The case of industrial districts. European Planning Studies, 10(4), 449-466.

European Commission. (2009). Final Report of the Expert Group. Overview of Family-Business-Relevant Issues: Research, Networks, Policy Measures and Existing Studies.

European Parliament. (2015). Industry 4.0: Digitalization for Productivity and Growth. Brussels: European Parliamentary Research Service (EPRS).

Giuliani, E. (2007). The selective nature of knowledge networks in clusters: Evidence from the wine industry. Journal of Economic Geography, 7(2), 139-168.

Golinelli, G. M. (2000). L'approccio sistemico al governo dell'impresa (Vol. 1). Padova: Cedam.

Götz, M., \& Jankowska, B. (2017). Clusters and Industry 4.0 - Do they fit together? European Planning Studies, 25(9), 1633-1653.

Hervás-Oliver, J. L., Albors-Garrigos, J., Estelles-Miguel, S., \& Boronat-Moll, C. (2018). Radical innovation in Marshallian industrial districts. Regional Studies, 52(10), 1388-1397.

Hervás-Oliver, J. L., Sempere Ripoll, F., Estelles-Miguel, S., \& Rojas. (2019). Radical vs incremental innovation in Marshallian industrial districts in the Valencian region: What prevails? European Planning Studies, 27(10), 1924-1939.

Hess, M. (2004). "Spatial" relationships? Towards a reconceptualization of embeddedness. Progress in Human Geography, 28(2), 165-186.

Ingram, A. E., Lewis, M. W., Barton, S., \& Gartner, W. B. (2016). Paradoxes and innovation in family firms: The role of paradoxical thinking. Entrepreneurship Theory and Practice, 40(1), 161-176.

Intesa San Paolo. (2018). Economia e finanza dei distretti industriali. Rapporto annuale - n. 11.

ISTAT. (2011). I distretti industriali. Report 2011.

Italian Ministry of Economic Development. (2017, August). Italy: "Industria 4.0”. Italy: Digital Transformation Monitor. 
Kang, H. S., Lee, J. Y., Choi, S., Kim, H., Park, J. H., Son, J. Y., Kim, B. H., \& Noh, S. D. (2016). Smart manufacturing: Past research, present findings, and future directions. International Journal of Precision Engineering and Manufacturing Green Technology, 3(1), 111-128.

Kellermanns, F. W., Eddleston, K. A., Sarathy, R., \& Murphy, F. (2012). Innovativeness in family firms: A family influence perspective. Small Business Economics, 38(1), 85-101.

Kim, K., Haider, Z. A., Wu, Z., \& Dou, J. (2019). Corporate social performance of family firms: A place-based perspective in the context of layoffs. Journal of Business Ethics, forthcoming.

Kraus, S., Pohjola, M., \& Koponen, A. (2012). Innovation in family firms: An empirical analysis linking organizational and managerial innovation to corporate success. Review of Managerial Science, 6(3), 265-286.

Lambooy, J. G. (2010). Knowledge transfers, spillovers and actors: The role of context and social capital. European Planning Studies, 18(6), 873-891.

Lattanzi, N. (2017). Le aziende familiari. Generazioni Società Mercato. Torino: Giappichelli.

López-Gracia, J., \& Sánchez-Andújar, S. (2007). Financial structure of the family business: Evidence from a group of small Spanish firms. Family Business Review, 20(4), 269-287.

Malecki, E. J. (2012). Regional social capital: Why it matters. Regional Studies, 46(8), 1023-1039.

Mandl, I. (2008). Overview of Family Business Relevant Issues. Vienna: Austrian Institute for SME Research.

Moeuf, A., Pellerin, R., Lamouri, S., Tamayo-Giraldo, S., \& Barbaray, R. (2018). The industrial management of SMEs in the era of Industry 4.0. International Journal of Production Research, 56(3), 1118-1136.

Muscio, A. (2006). Patterns of innovation in industrial districts: An empirical analysis. Industry and Innovation, 13(3), 291-312.

Nieto, M. J., Santamaria, L., \& Fernandez, Z. (2015). Understanding the innovation behavior of family firms. Journal of Small Business Management, 53(2), 382-399.

Pearson, A. W., Carr, J. C., \& Shaw, J. C. (2008). Toward a theory of familiness: A social capital perspective. Entrepreneurship Theory and Practice, 32(6), 949-969.

Pucci, T., Brumana, M., Minola, T., \& Zanni, L. (2017). Social capital and innovation in a life science cluster: The role of proximity and family involvement. The Journal of Technology Transfer, 45(1), 205-227.

Raco, M. (1999). Competition, collaboration and the new industrial districts: Examining the institutional turn in local economic development. Urban Studies, 36(5-6), 951-968.

Randelli, F., \& Boschma, R. (2012). Dynamics of industrial districts and business groups: The case of the Marche region. European Planning Studies, 20(12), 1961-1974.

Randoy, T., Jenssen, J., \& Goel, S. (2003). Family Firms and Good Corporate Governance: Altruism and Agency Considerations. Norway: Agder Maritime Research Foundation.

Salvato, C., \& Melin, L. (2008). Creating value across generations in familycontrolled businesses: The role of family social capital. Family Business Review, 21(3), 259-276. 
Santarelli, E. (2004). Patents and the technological performance of district firms evidence for the Emilia-Romagna Region of Italy (No. 2904). Papers on Entrepreneurship, Growth and Public Policy.

Schmidt, R., Möhring, M., Härting, R.-C., Reichstein, C., Neumaier, P., Jozinović, P. (2015). Industry 4.0 - Potentials for creating smart products: Empirical research results. Lecture Notes in Business Information Processing, 208, 16-27.

Schumpeter, J. (1934). The Theory of Economic Development. Cambridge, MA: Harvard University Press.

Schwab, K. (2017). The Fourth Industrial Revolution. New York: Crown Publishing Group

Sforzi, F. (2002). The industrial district and the "new" Italian economic geography. European Planning Studies, 10(4), 439-447.

Signorini, L. F. (1994) The price of Prato, or measuring the industrial district effect. Papers in Regional Science, 73(4), 369-392.

Smith, C. (2016). Environmental jolts: Understanding how family firms respond and why. Family Business Review, 29(4), 401-423.

Soleimanof, S., Rutherford, M. W., \& Webb, J. W. (2018). The intersection of family firms and institutional contexts: A review and agenda for future research. Family Business Review, 31(1), 32-53.

Storper, M. (1993). Regional "worlds" of production: Learning and innovation in the technology districts of France, Italy and the USA. Regional Studies, 27(5), 433-455.

Stough, R., Welter, F., Block, J., Wennberg, K., \& Basco, R. (2015). Family business and regional science: "Bridging the gap." Journal of Family Business Strategy, 6(4), 208-218.

Tagiuri, R., \& Davis, J. A. (1992). On the goals of successful family companies. Family Business Review, 5(1), 43-62.

Wang, L., \& Wang, G. (2016). Big data in cyber-physical systems, digital manufacturing and industry 4.0. International Journal of Engineering and Manufacturing, 6(4), 1-8.

Zahra, S. A. (2010). Harvesting family firms' organizational social capital: A relational perspective. Journal of Management Studies, 47(2), 345-366.

Zahra, S. A., \& Sharma, P. (2004). Family business research: A strategic reflection. Family Business Review, 17(4), 331-346. 